\title{
VE SLUŽBÁCH ČESKOSLOVENSKA. ARCHEOLOGICKÝ VÝZKUM PRAŽSKÉHO HRADU VE 20. STOLETÍ
}

\author{
JANA MAŘÍKOVÁ-KUBKOVÁ
}

\begin{abstract}
Abstrakt: Historie výzkumu Pražského hradu se ve dvacátém století prolíná s historii Československa a České republiky. Hrad je od roku 1918 upravován pro nově přichozi prezidenty, z nichž někteři měnili zásadním způsobem život celé společnosti. Většina z nich (nebo z jejich aparátu) se snažila symbolicky využit tisíciletou historii mista a prebudovat jej na základě myšlenek své doby. Výrazné změny se udály ve 20. letech po nástupu Tomáše Garrigua Masaryka. Dalši pak mély nastat v období po druhé světové válce za prezidentů Klementa Gottwalda a jeho následovniků. Ty největši se, možná naštěstí, neuskutečnily. Nové impulzy přišly s prezidentem Václavem Havlem po roce 1990. U v̌̌ech prestaveb, nových interpretaci a formativních výstavnich počinů týkajicich se českého středověku jsou od roku 1925 archeologové Archeologického ústavu v Praze.
\end{abstract}

Klíčová slova: Pražský hrad - historie archeologického výzkumu - Ivan Borkovský - raný středověk.

\section{In the service of Czechoslovakia. Archaeological research into Prague Castle in the 20th century}

Abstract: The history of research into Prague Castle in the 20th century intertwines with the history of Czechoslovakia and the Czech Republic. Since 1918 the castle has been modified for the needs of the newlyarriving presidents, some of whom have significantly changed the life of the whole society. The majority of them (or their management) have tried to make symbolic use of the thousand-year history of the site and to transform it, based on the ideology of their era. Major changes took place in the 1920s after the arrival of Tomáš Garrigue Masaryk, and further changes were planned for the period after the Second World War, under President Klement Gottwald and his successors. It is perhaps fortunate that the most radical ones were not implemented. New stimuli came with President Václav Havel after 1990. Since 1925, archaeologists from the Institute of Archaeology in Prague have been involved in all reconstructions, new interpretations and formative exhibition projects regarding the Middle Ages in the Czech lands.

Key words: Prague Castle - history of archaeological research - Ivan Borkovský - early Middle Ages.

\section{Úvod}

Snad každá stat' o Pražském hradě začíná líčením jeho výjimečnosti nejen ve spojitosti s historií českých zemí, ale i v evropském měřítku. Ústřední sídlo hlavních církevních i světských institucí, které se zde utvářely od raného středověku, je jedním z hlavních témat bádání o českých dějinách nejpozději od první poloviny 19. století. Představy o jeho středověké a raně novověké historii na sebe vždy vzájemně působily s představami o celé české historii a prrímo ovlivňovaly formování české národní identity - a je tomu tak dosud. Tato skutečnost podněcovala nejen neutuchající zájem odborné i laické veřejnosti, prostor pro odbornou práci a finanční prostředky, ale také interpretace výsledků výzkumů, které podléhaly dobovým diskurzům a společenské poptávce.

Historii archeologického výzkumu Pražského hradu zmiňují pojednání v četných publikacích (např. Borkovský 1969; 8-11; 2005; ${ }^{1}$ Frolík-Smetánka 1997, 15-23; Frolík 2008; Maříková-Kubková 2008) a věnovaly se jí i mnohé výstavy, ${ }^{2}$ na skutečné vyhodnocení ale ještě čekáme. Nejvíce pozornosti zatím bylo věnováno jeho vzniku ve druhé polovině 19. století (naposledy Maříková-Kubková a kol. 2019, 686-689) a v období mezi dvěma světovými válkami. Etapa archeologického výzkumu po druhé světové válce se stala jedním $\mathrm{z}$ hlavních témat $\mathrm{v}$ rámci

1 Text pochází z pozůstalosti dr. Ivana Borkovského, který po jeho úmrtí po delším časovém odstupu editoval dr. Jan Frolík a má velkou vzpomínkovou hodnotu.

2 Archeologické poklady Pražského hradu, Starý královský palác, Správa Pražského hradu, 1997; Obnova Pražského hradu mezi lety 19181929, Pražský hrad, Tereziánské křídlo, řijen 2017 - květen 2018, Správa Pražského hradu, Archeologický ústav AV ČR, Praha, v. v. i. Archeologické poznatky a nálezy jsou také základem stálé expozice Př́iběh Pražského hradu (od 2003). 
aktuálních projektů Strategie AV21 a TA ČR. $\mathrm{K}$ úkolu můžeme přistoupit několika způsoby. První, dosud využívaný, bere v potaz úspěchy a pády pracoviště na základě uskutečněných výzkumů, vydaných knih, zpracování nálezových celků a jejich výpovědi. Další možnost, a já ji pro potřeby této publikace upřednostňuji, nabízí zkoumání vztahu Archeologického ústavu, Kanceláře prezidenta republiky (dále jen KPR) a dalších institucí, které se podílely na průzkumu a rekonstrukcích hradních budov. Máme tak jedinečnou prríležitost, abychom získali plastický obraz významu archeologie a respektu, který si v určitých obdobích vydobyla, požadavků, které na ni byly kladeny, ale i mantinelů, v nichž se pohybovala. Zatímco $\mathrm{v}$ prrípadě prvního uvedeného prístupu se pracuje především s odbornými výstupy, v př́ípadě druhém je nutné zpracovat rozsáhlé archivní fondy. Za všechny jmenujme Fond Stavební správy z let 1919-1948, osobní fondy Karla Fialy a Pavla Janáka, všechny uložené v Archivu Pražského hradu (dále APH). Agendu k archeologickým výzkumům lze nalézt také $\mathrm{v}$ Archivu Kanceláře prezidenta republiky (dále AKPR). Odbornou dokumentaci, posudky, projekty a podobně je možné konzultovat v APH, ve Sbírce nových plánů, stavebněhistorických průzkumech a sbírkách fotografií. Práce v APH a APKR aktuálně probíhají, proto mohu v následujících řádcích popsat jen jejich předběžný výsledek. Soustředím se na terénní výzkumy, jejich organizaci, využití a interpretaci týkající se Pražského hradu, na vztah mezi Archeologickým ústavem Akademie věd ČR a KPR, úlohu vedoucích osobností a vývoj celkové prredstavy o stavební podobě Hradu v jednotlivých historických obdobích a její přesah do obecného povědomí. Vzhledem k omezenému rozsahu publikace ponechám stranou zpracování nálezových celků a příspěvek pracoviště k celkovému poznávání středověké materiální kultury. V rovině vztahu s KPR šlo spíše o otázky zřízení depozitářů a několik projektů muzea. Této tematice se zde až na výjimky bohužel nemohu věnovat.

\section{Před rokem 1918}

Svoji významnou pozici mezi habsburskými rezidencemi ztratil Pražský hrad již před polovinou 19. století (Halata-Karasová-Šula 2013), ale s postupujícím národním obrozením získal na atraktivitě nejen u české části společnosti. ${ }^{3}$ Významným posunem bylo založení Jednoty pro dostavbu katedrály sv. Víta (Petrasová 2019, 522-525). Poznatky o podobě stř̌edověkého a raně novověkého

3 Jak nás zpravuji Ročenky Jednoty pro dostavbu chrámu sv. Víta (1861-1952), například na tuto stavbu př́ispívaly všechny společenské vrstvy česky i německy mluvících obyvatel. 
Pražského hradu, utváření jeho areálů a stavebního vývoje hlavních církevních i rezidenčních budov vycházely z počátku z písemných pramenů; ${ }^{4}$ od 70 . let 19 . století je navíc obohacují archeologické a stavebněhistorické průzkumy. Spolupráci stavitelů, architektů a archeologů zahájila ve druhé polovině 19. století rekonstrukce a dostavba katedrály sv. Víta. Pod vedením architektů Josefa Mockera a Kamila Hilberta byly od konce 70. let 19. století do konce 20. let století následujícího postupně odkryty části románské trojlodní baziliky s kapitulou a předrománské rotundy (naposledy Maříková-Kubková a kol. 2019, 20-31, 48-89). V tomto období paralelně probíhaly práce i v bazilice sv. Jiří (naposledy Mašterová 2015). Nejvýznamnějším objevem, kterým archeologie ve svých počátcích výrazně přispěla k budování symboliky Pražského hradu, byl nález místa původního uložení hrobu sv. Václava $\mathrm{v}$ jižní apsidě předrománské svatovítské rotundy v roce 1910 (Hilbert 1915; 1917). Objev měl velkou odezvu u veřejnosti a předznamenal archeologické práce vedené ve 20. letech Kamilem Hilbertem a Františkem X. Margoldem.

V 19. století vznikla také stále aktuální a oblíbená disciplína: rekonstrukce stavebních podob Pražského hradu v jednotlivých časových obdobích, tehdy ovšem založená především na písemných pramenech (Herold 1884).

\section{První československé desetiletí}

Rozhodujícím posunem v chápání, rozsahu a kvalitě výzkumu a průzkumu se stal rok 1918. Okamžitě byly zahájeny stavební práce, aby přeměnily částečně zanedbaný Hrad v sídlo prvního československého prezidenta, které naváže na tisíciletou historii místa. Ve Stavebních denících stavitele Karla Fialy (Deník 1918-1919) se od poloviny listopadu toho roku dočítáme o úklidu veřejných prostranství, nutných stavebních úpravách, přípravě na zavedení nové kanalizace a elektrifikaci. Karel Fiala prováděl průzkumy již před první světovou válkou, např́íklad ve Starém královském paláci (Měchura 2016, 66-68), a tudíž jen rozšířil svoji působnost. Jedním z míst, které mělo doznat zásadních úprav, bylo III. nádvoří. Při jeho přestavbě byly učiněny velké a přkvapivé objevy. Nejprve bylo př̀i průkopu pro novou kanalizaci odkryto románské zdivo, od začátku považované za součást areálu svatovítské baziliky. V roce 1922 byl v úplnosti odhalen půdorys jednolodní kaple s chodbou směřující na sever, k bazilice. Nálezy probudily zájem odborníků i širší veřejnosti a prakticky okamžitě bylo rozhodnuto, že se tato památka zachová (naposledy s literaturou Maříková-Kubková a kol. v tisku). Vzniklo tak jádro archeologického areálu pod III. nádvořím, který byl posléze rozšířen, aby ochránil části nejstarších opevnění, základy kamenných a dřevěných domů a další památky. Zároveň byla na III. nádvoří od počátku věnována pozornost nálezům, keramice, sklu a architektonickým článkům nejen středověkým, ale i raně novověkým (Blažková-Svobodová 2020, 889-905).

V roce 1924 byla zrŕzzena Archeologická komise pro výzkum Pražského hradu sestavená ze zástupců Univerzity Karlovy, Státního archeologického ústavu (dále jen StAÚ), Národního muzea, ministerstva školství, ministerstva veřejných prací, KPR a její Stavební správy. V čele komise stál Lubor Niederle a ze známých odborníků byli jejími členy např́ílad Albín Stocký, Vojtěch Birnbaum, Karel Guth, Karel Buchtela a samozřejmě i Karel Fiala, tehdy již ředitel Stavební správy (Borkovský 1969, 8-9). Jak práce postupovaly, ukazovalo se, že pro Karla Fialu je náročné současně vést stavební práce, Stavební správu, výzkumné a rekonstrukční práce ve Starém královském paláci a k tomu všemu ještě archeologický výzkum (Měchura 2016, 144-146). Navíc bylo jasné, že pro poznání historie Hradu budou zásadní nejen III. nádvoří, ale i ostatní části a že archeologický výzkum bude zastávat významnou úlohu. Vedením systematického výzkumu, který měl být vykonáván moderními prostředky, proto komise pověřila Karla Gutha. Práce byly zahájeny ve čtvrtek 4. června 1925. Jak vyplývá z deníků (Deník 1925), v terénu se pohybovali tehdy mladí pracovníci StAÚ Jaroslav Böhm, Jan Filip, Jaroslav Pasternak a Ivan Borkovský,

4 Nejvýznamnějším autorem tohoto období je Václav Vladivoj Tomek, přehled všech jeho publikací však není možné na tomto místě uvést. K hlavním dílům patři Základy mistopisu pražského (1865), Dějepis města Praha (1855-1901) a jeho texty k jednotlivým hradním církevním stavbám. 
a tak se toto datum všeobecně považuje za oficiální den založení pracoviště StAÚ, i když jeho etablování bylo otázkou ještě dalších několika let. Karel Guth vedl výzkum i nadále a v roce 1926 se jeho asistentem stal právě Ivan Borkovský, který Pražskému hradu zasvětil valnou část svého odborného života.

Organizačně šlo o velmi náročný úkol, jejž financovaly Ministerstvo školství a národní osvěty a Magistrát hlavního města Prahy. Největšími investicemi ale přispívala Stavební správa Pražského hradu, která zajištovala i následné práce spojené s konzervací dochovaných památek, stavbou ochranných staveb a zastřešení archeologického areálu na III. nádvoří. Archeologické pracoviště bylo součástí StAÚ, ovšem velmi úzce spolupracovalo s KPR a jeho Stavební správou, archeologové byli částečně nebo úplně, až do 30 . let, jejími zaměstnanci.

Výsledky archeologických výzkumů se dostávají do širšího povědomí s určitým zpožděním. Platí to i pro jejich implementaci do obecnějšího diskurzu. Jakkoli bylo prvních deset let Československé republiky zasvěceno přestavbě Hradu na sídlo československého prezidenta, výsledky záchranného a svým způsobem i systematického výzkumu se v publikacích objevují až později. Ve 20. letech se postupně veškeré snažení soustředilo na Svatováclavské milénium v roce 1929 (Maříková-Kubková 2019). K němu se upínaly snahy nejen architektů a stavitelů, ale i archeologů, historiků a kunsthistoriků. Měla být dokončena přestavba, zpř́ístupněny archeologické areály pod III. nádvořím (propojením na sloupovou síň Starého královského paláce), tzv. Malé vykopávky a prostor Královské hrobky. Publikace se měl dočkat Svatováclavský sborník (Guth-Kapras-Novák 1934), který se stal svým způsobem kanonickou prací a v němž Josef Cibulka (1934) zveřejnil nově zpracované výzkumy Kamila Hilberta. Především jeho interpretace rotundy sv. Víta se na téměř jedno století stala jedinou platnou (Frolík et al. 2000, 145-208). Archeologové se ale také vrátili k tématům, která rezonovala již od 19. století. Jako př́íklad jmenujme otázku polohy kostela Panny Marie (naposledy Maříková-Kubková 2019b) či celkové podoby Pražského hradu v raném středověku. K tématu přispěl Karel Fiala (1933) rekonstrukcí románské fáze.

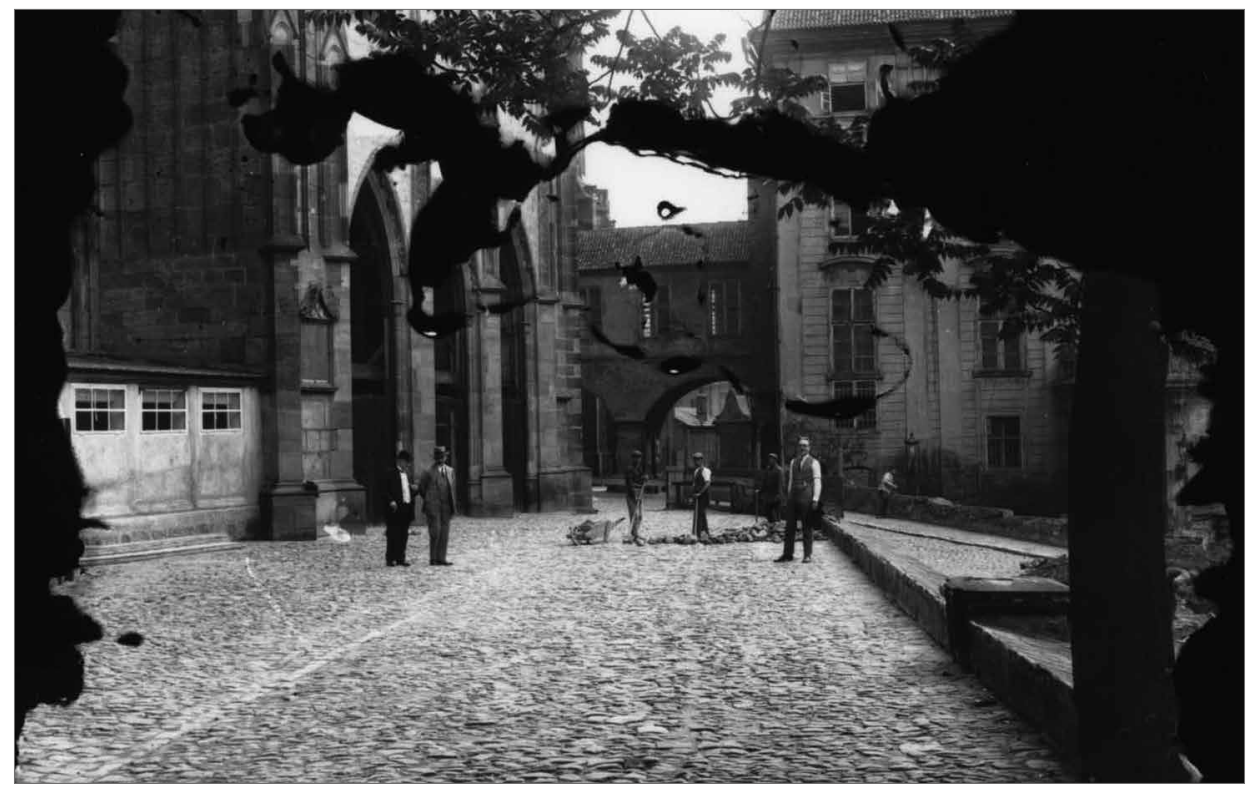

Obr. 2. Pražský hrad, 4. června 1925, zahájení výzkumu v severní části III. nádvoří. (Negativ byl poškozen při povodni v roce 2002.) Zdroj ARÚ - pracoviště PH, C03026.

Abb. 2. Prager Burg, 4. Mai 1925, Grabungsbeginn im Nordteil des III. Burghofs. (Das Negativ der Aufnahme wurde während des Hochwassers von 2002 beschädigt.) Quelle Archäologisches Institut der Akademie der Wissenschaften in Prag, Abteilung Prager Burg, C03026. 
Záznam ze dne 28. května 1925:

Dostavil se prof. Dr. Lubor $N i$ e a e r-

I e a pođává zpráva o prưběhu spolec̆né komise, svolané $k$ určeni postupu při archaeologickém proziroumáni III. nádvoři. Zpráva shoduje se s obdobnou zprávou odboru III. - Upozorňaje na stanovisko p. stavitele Fialy, který klamně se citil komisi odstrěen a žédá $v$ té přičině, kdyby bylo zapotrebí, o smírné zasaženi. Jinak ubezpečaje, že pánové, kteří při výkopech dozor povedou, budou všeomožně se stavitelem p. Fialou vdržovati př́telský styk.
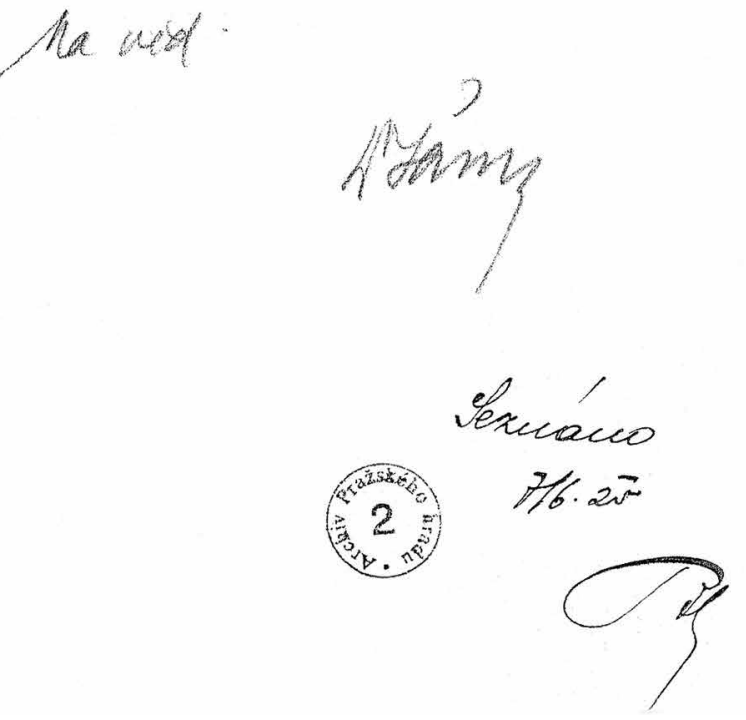

Obr. 3. Vznik Archeologické komise a počátky působení archeologů vedle stavitele Karla Fialy se neobešly bez problémů. Zdroj APH, Stavební věci Pražského hradu KPR 1919-1947, inv. č. 445.

Abb. 3. Die Entstehung der Archäologischen Kommission und die Anfänge ihrer Zusammenarbeit mit Baumeister Karel Fiala waren nicht problemlos. Quelle Archiv der Prager Burg, Bauangelegenheiten der Prager Burg, Kanzlei des Präsidenten der Republik 1919-1947, Inv.- Nr. 445. 


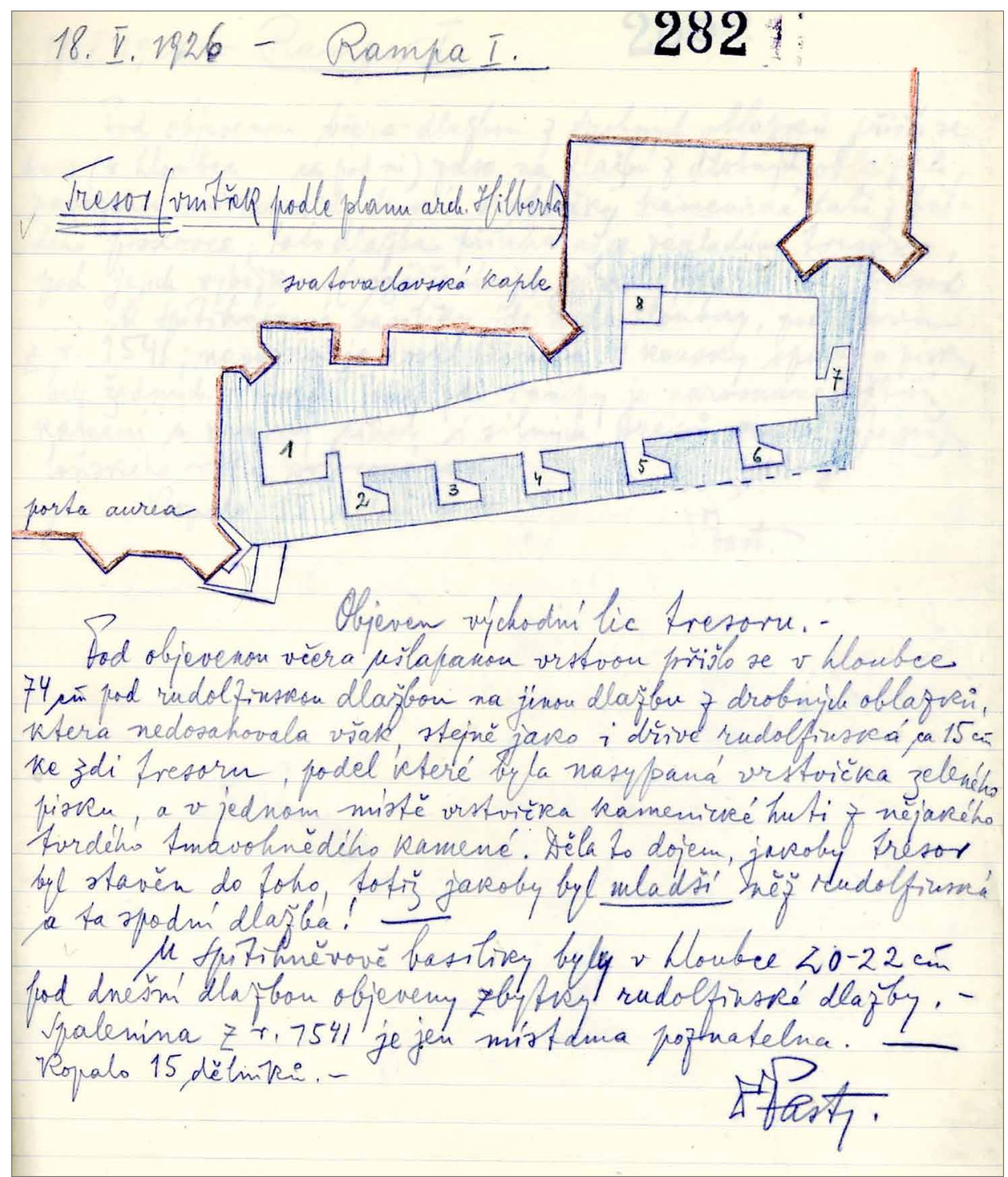

Obr. 4. Deník 1926, 18. 5. 1926, určení stáří tzv. tresoru pomocí stratigrafie, podepsán Jaroslav Pasternak. Zdroj APH, fond Stavební správy, inv. č. Ss IX, 1-3.

Abb. 4. Tagebucheintrag vom 18. 5. 1926, Altersbestimmung des sog. Tresors mittels Stratigraphie, unterschrieben von Jaroslav Pasternak. Quelle Archiv der Prager Burg, Sammlung der Bauverwaltung, Inv.-Nr. Ss IX, 1-3.

\section{Období druhé světové války}

Válečné období terénní aktivity utlumilo. V roce 1936 byl jmenován hradním architektem Pavel Janák, který se během vynucené válečné přestávky spolu s Ivanem Borkovským snažil, aby pokračovala alespoň nejnutnější údržba archeologického areálu pod III. nádvořím. Spolupracovali s odborníky i z jiných institucí (Kloknerův ústav, Ústav teoretické a aplikované mechaniky). Péče, kterou takto nastavili, byla posléze dokumentována na počátku 60. let (viz dále). Prováděly se geodetické práce (APH Zs 580/44), v letech 1942-1943 se také uskutečnila inventarizace 


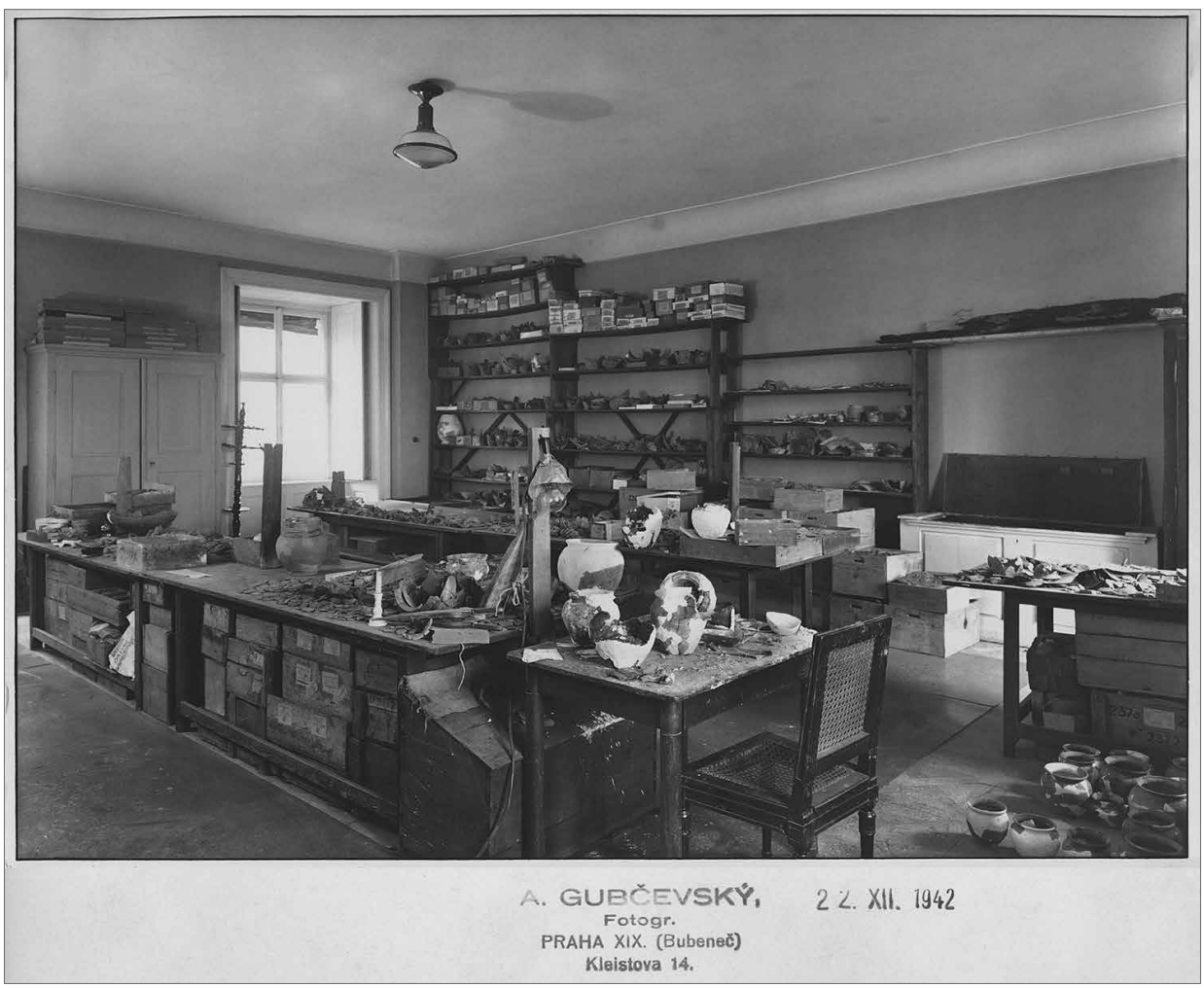

Obr. 5. Pohled do pracovny Ivana Borkovského v roce 1942. Foto Andrej Gubčevskij. Zdroj APH, fond Stavební správy 1371/42. Abb. 5. Blick ins Arbeitszimmer von Ivan Borkovský 1942. Foto Andrej Gubčevskij. Quelle Archiv der Prager Burg, Sammlung der Bauverwaltung 1371/42.

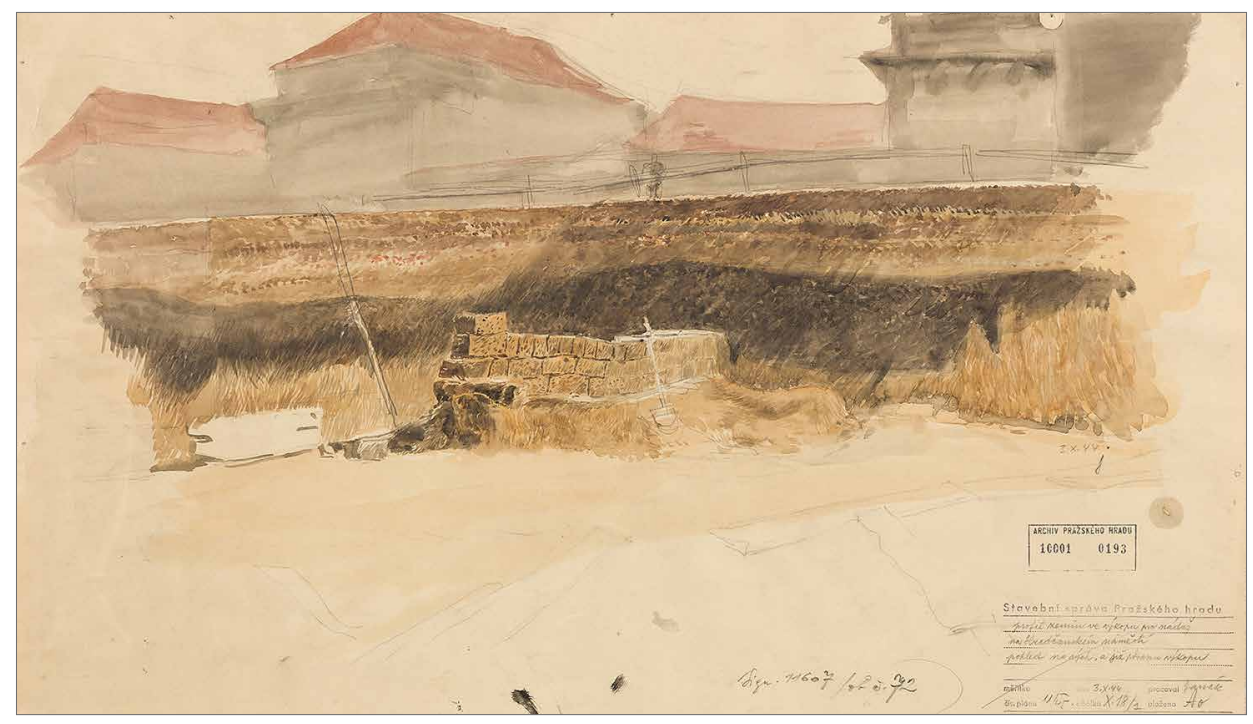

Obr. 6. Hradčanské nám., ř́ijen 1944, výzkum románského domu. Kresba Pavel Janák. Zdroj APH fond Stavební správy, 10001/0193. Abb. 6. Hradschiner Platz, Oktober 1944, Ausgrabung eines romanischen Hauses, Zeichnung Pavel Janák. Quelle Archiv der Prager Burg, Sammlung der Bauverwaltung, 10001/0193. 
sbírkového fondu (APH 15240/44; APH Ss 313/44). O nálezy a archeologické areály se zajímal Karl Maria Swoboda, k pochopení jeho role však zatím nemáme dost dokumentů, ale podle všeho byl i přímluvcem za Ivana Borkovského a pomáhal bránit některým nevhodným stavebním zásahům (APH Zs 580/44). Pavel Janák a Ivan Borkovský celou válku pracovali též na přiměřeném uložení nálezových celků (APH Ss1190/42). Jedinou větší terénní příležitostí se zajímavým výsledkem byl záchranný výzkum při hloubení výkopu pro velkou požární nádrž uprostřed Hradčanského náměstí na podzim roku 1944. Byly při něm objeveny a dokumentovány základy románského domu (APH Ss 1001/0193), které byly posléze přeneseny do archeologického areálu pod III. nádvořím. Nebezpečí bombardování zasáhlo i péči o Pražský hrad. Největším úkolem bylo zabezpečení významných budov, např́iklad katedrály sv. Víta (Šindelková 2019, 780-790; Vobořilová-Kadlecová 2019,68). Válečný stres působil i na Ivana Borkovského. Když ředitel památkového úřadu K. F. Kühn rozhodl, že se nálezový fond nebude z Pražského hradu stěhovat a ukrývat, jak se dělo s jinými významnějšími uměleckými díly, protože je na Hradě víceméně v bezpečí, Borkovský si nechal vystavit zvláštní průkaz, aby v př́ípadě útoku mohl zůstat na místě (APH Zs 580/44).

\section{Období po druhé světové válce}

Stejně jako byl po roce 1918 Pražský hrad přebudován na rezidenci prvního československého prezidenta, také po roce 1948 došlo k jeho zásadnímu významovému posunu. Nové úpravy jej měly přeměnit na sídlo tzv. dělnických prezidentů. Období mezi lety 1948 až 1956 je hodnoceno jako dogmatické, a vedlo spíše k uzavírání areálu (Rollová 2019, 29-39; Bartlová v tisku). Pro archeologii se ale svým způsobem nic nezměnilo. Archeologický výzkum měl nadále charakter výzkumu záchranného. V nejasném období mezi lety 1945-1950 se financování dělilo mezi KPR a StAÚ (APH 402 902/50). V roce 1950 byl učiněn pokus sladit potřeby staveb s výzkumným plánem tak, aby si StAÚ mohl dát výzkum Hradu, jako nejvýznačnější památky v Československu, do svého plánu (APH 402759/1950). V listopadu roku 1953 byla uzavřena Dohoda o způsobu práce archeologického výzkumu na Pražském hradě (APH 304050/53), ${ }^{5}$ která se od všech smluv budoucích mnoho neliší. Konstatuje, že ARÚ je vědecké pracoviště s povinností pečovat o záchranné výzkumy, archeologické areály a nálezové soubory a KPR mu k tomu zajišt’uje podmínky a financování.

Památková správa zůstala spojena se stavební správou. Protože Pražský hrad čekala rozsáhlá přestavba, která se dotýkala všech hlavních památek, byly postupně angažovány i další instituce. Od 50. let 20. století stavebněhistorické průzkumy vedl Ústav dějin umění Československé akademie věd (dále ÚDU). ${ }^{6}$ Ještě v jejich průběhu zde začal působit Státní ústav pro rekonstrukci památkových měst a objektů (dále SÚRPMO), který se postupně stal generálním dodavatelem stavebních průzkumů a některých projekčních prací a jehož aktivity byly zvlášt' významné v 70. letech 20. století (APH 403744/59). Výběrem architektů a dohledem nad architektonickou úrovní prací byl pověřen Svaz československých architektů, respektive jeho předsednictvo (APH 403744/59). Již od předválečného období s archeology spolupracovaly i další instituce, především v péči o archeologické areály, za všechny jmenujme např́ílad Kloknerův ústav nebo ÚTAM. Kancelář prezidenta republiky navíc zřizovala různé rady a komise. Ještě před rokem 1950 zde působila Umělecká komise, jejímiž členy byli např́ílad A. Matějček nebo V. V. Štech (Rollová 2019, 39). V průběhu 50. let se jejich struktura různě proměňovala. Asi největší význam měla Ideová rada (1957-1969) a její odnože. Ve všech působil až do své smrti akademik Jaroslav Böhm († 1962) a do konce 60. let Ivan Borkovský († 1976). Z dochovaných dokumentů vyplývá, že se posledně jmenovaný těšil velkému respektu, a to jak u hradního architekta Pavla Janáka

\footnotetext{
5 Podobná smlouva byla uzavřena is Ústavem dějin umění.

6 Problematiku spolupráce mezi ARÚ a ÚDU ilustruje spor o Svatojiřskou baziliku mezi Ivanem Borkovským a Anežkou Merhautovou, který uzavřely dvě samostatné monografie (Borkovský 1968; 1975; Merhautová 1966), ačkoli v korespondenci mezi KPR, ARÚ a ÚDU je patrný silný tlak na dohodu a společný postup.
} 
(† 1956), tak u dalších tvůrců a inženýrů, kteří na Hradě působili. V roce 1967 mu bylo propůjčeno prezidentem republiky vyznamenání Za vynikající práci za jeho celoživotní dílo. ${ }^{7}$

Okamžitě po konci války byl dokončován výzkum pod Severním palácovým dvorkem, který, obdobně jako III. nádvoří, měla překrýt betonová deska vynesená na železobetonových sloupech (APH 401 167/48). Byla dokončena ještě před rokem 1950. Za nejvýraznější osobnost tohoto období mezi projektanty je považován Bedřich Hacar, který měl za sebou již práci s Josipem Plečnikem a před sebou vynesení železobetonového stropu nad starší fází kláštera sv. Jiří s Františkem Cubrem a Josefem Pilařem. Během druhé světové války byl vypracován postup, jak pečovat o archeologické terény pod III. nádvořím, speciálně o fragmenty dřevěných konstrukcí, který byl přesně popsán až v mladších textech, použité chemikálie se ale objevují v nákupech už ve 40. letech. ${ }^{8}$ Vztah k vykopávkám se však proměňoval, jak dokládá série dokumentů, které se zabývají povolováním vstupu pod III. nádvoří. Právo k návštěvě měl jen „užší okruh odborníkư““ (APH 402 138/60) s ohledem na jejich bezpečnost (tamtéž), ale také s ohledem na jejich specializaci (APH 401753/60). Během rekonstrukce Starého královského paláce se v roce 1964 znovu uvažovalo o zpřístupnění alespoň východní části areálu s kostelem zvaným sv. Bartoloměje (APH 400044/64). Analogicky se objevila myšlenka zpř́istupnit i kostel Panny Marie v objektu Obrazárny. Došlo k tomu však jen na krátkou dobu, respektive vůbec. Na rozdíl od archeologických areálů ve 20. letech velkoryse koncipovaných pro širokou veřejnost, u nově vzniklých se počítalo spíše s jejich významem pro odborníky.

Uvnitř ústavu si pracoviště zachovávalo autonomní postavení a stalo se jádrem budoucího Oddělení archeologie středověku. V 50. a 60. letech zde pod vedením Ivana Borkovského začínaly a vyrůstaly osobnosti, které jsou dnes považovány za zakladatelskou generaci české středověké archeologie - Miroslav Richter, Zdeněk Smetánka či stále ještě aktivní dlouholetý vedoucí výzkumu Vyšehradu Bořivoj Nechvátal. Práce na Hradě však I. Borkovský vedl výlučně sám. Pokračoval ve své práci z předchozího období a hned v roce 1950 vzbudil velký zájem dokončením výzkumu kostela Panny Marie (Borkovský 1951; 1953). Uzavřel jedno století pátrání po stavbě, kterou měl podle legend založit kníže Bořivoj. ${ }^{9}$ Stalo se tak v době, kdy se znovu formoval kánon raných českých a moravských dějin pro nové, poválečné Československo. O významu objevu a možnostech jeho interpretace vypovídá diskuse publikovaná v roce 1951. Vedle odborných autorit se jí aktivně účastnil vlivný komunistický historik a přednosta Politického archivu kanceláře prezidenta republiky Jan Pachta (1951, 46-52) a František Nečásek, přednosta kulturního a tiskového odboru KPR (1951, 15-19). Autorovi výzkumu Ivanu Borkovskému bylo tlumočeno blahopřání prezidenta Klementa Gottwalda (APH 116516/50).

Poválečné období charakterizují nejen ambice Hrad velkoryse přestavět (Rollová 2019, 143), ale i smutné kapitoly řízeného chátrání některých, především církevních staveb. Za všechny jmenujme klášter a baziliku sv. Jiř́, v nichž v roce 1946 nahradili vojáci hradní stráže arcibiskupskou konzistoř (H2240/46). V roce 1957 byl konstatován jejich havarijní stav a navržena přestavba (APH 404686/58) nejprve na muzeum Pražského hradu, ${ }^{10}$ později na Památník dějin československého lidu, aby v ní nakonec své sídlo získala Národní galerie. Pro Ivana Borkovského a jeho tým to znamenalo velké množství práce. $K$ největším akcím patřily právě výzkumy v bazilice a klášteře sv. Jiří. Opakovaně ho zaměstnávaly i práce ve Starém královském paláci, které navazovaly na postupnou rekonstrukci pro stálou expozici. Krom prací v areálu Hradu a jejich zpracování plánovali pracovníci ARÚ i další projekty pro novou náplň hradních objektů. Patřil k nim mimo jiné velkorysý plán muzea Husitského revolučního hnutí, pro nějž měl Miroslav Richter zpracovat výzkum v Sezimově Ústí (APH 400 368/63).

7 Vyznamenání obdržel, přestože byl nestraník, nijak se politicky neangažoval a z jeho životopisu vyplývá, že měl v životě momenty, které nemohly vyhovovat soudobým představám o laureátech státních cen. Možná i proto mu bylo propůjeceno vyznamenání nejnižší.

8 V roce 1962 nakoupila KPR $25 \mathrm{~kg}$ kyseliny karbolové, $20 \mathrm{~kg}$ lněného oleje, $15 \mathrm{~kg}$ terpentýnu a $15 \mathrm{~kg}$ technického glycerinu a vše předala pracovníkovi ARÚ (APH 402380/62).

$9 \mathrm{~V}$ průběhu středověku se o něm ztratilo povědomí, hypotézu o jeho existenci vyslovil jako první V. V. Tomek (1850) a od té doby se po něm intenzivně pátralo.

$10 \mathrm{~V}$ dokumentech je zmiňováno i muzeum archeologických nálezů. 
S postupným odchodem Ivana Borkovského do penze nastává útlum jak terénní práce, tak činnosti archeologů v památkových a kulturních strukturách. Poslední doložená terénní dokumentace, kterou Ivan Borkovský odevzdal do Archivu KPR, pochází z ledna roku 1970, kdy jako třiasedmdesátiletý zakreslil nález klenuté štoly na Novozámeckých schodech (AKPR 400408/70).

Borkovského požadavek na dokumentaci prakticky každého výkopu, sledování geologických sond a schopnost spolupracovat se širokým spektrem odborníků a architektů nenašly v jeho následovníkovi Zdeňku Smetánkovi toho pravého pokračovatele. Sedmdesátá léta sice zahájil založením nového Oddělení archeologie středověku (Starcová 2019, 103) a výzkumem raně středověkého pohřebiště v Lumbeho zahradě (naposledy Frolík-Smetánka 2014), jinak ale pozici získanou Ivanem Borkovským postupně opouštěl. Částečně tento ústup zavinily personální změny v KPR po roce 1969, zčásti havarijní stav pracoviště a dočasné vystěhování do garážového dvora (AKPR 402 352/72), do jisté míry i jeho orientace na jiné otázky archeologie středověku. V Archivu KPR jsou dochovány dokumenty, ve kterých Zdeněk Smetánka rezignuje na některé typy prací (AKPR 405 136/71) nebo je velmi zjednodušuje (AKPR 402846/71). Stalo se tak, že archeologům unikly i významné počiny, jako bylo prozkoumání hrobů K1 a K2 náležejících k rotundě sv. Víta v roce 1974 (Vlček 1997). Jak přesně k tomu došlo, není zatím jasné. Mủžeme se opřít jen o vzpomínky pamětníků, ani v jednom z hradních archivů jsem prozatím nenalezla žádné relevantní dokumenty. Krom pohřebiště v Lumbeho zahradě, které bylo v úplnosti publikováno až péči Jana Frolíka (Frolík-Smetánka 2014), můžeme do 70. let datovat jen málo výzkumů, většinou je vedl a zpracoval Tomáš Durdík. Péče o archeologické terény se zúžila na areál pod III. nádvořím, kde se jí ve velmi omezené míře věnoval SÚRPMO. Z druhé poloviny 70. a z první poloviny 80 . let jsou zachovány především požadavky na expertizy a jejich výsledky, restaurátorské ani jiné práce se neodehrávaly (např. AKPR 401273/80).

Stejně jako v předešlých letech i nadále působení archeologů na Hradě umožňuje smlouva mezi ARÚ a KPR. Smlouvy se však obnovovaly nepravidelně. V terénu se situace na obou stranách, ARÚ i KPR, mění k lepšímu na počátku 80 . let. Na hradní pracoviště postupně nastoupili príslušníci nové generace Ivana Boháčová, Jan Frolík, záhy pověřený vedením terénních výzkumů, a Jaromír Žegklitz, v KPR Bedřicha Tykvu nahradil Petr Chotěbor. Především zásluhou P. Chotěbora a prostřednictvím jím vydávaných dílčích památkových směrnic se archeologická památková péče vrací na úroveň, jakou v rámci dobových možností budoval Ivan Borkovský. Na archeology čekaly rozsáhlé úkoly v budoucí Císařské konírně či na Jiřském náměstí.

Období od konce druhé světové války do pádu socialistického Československa lze vnímat jako tři stadia ve výzkumu a interpretaci Pražského hradu. V první etapě, v 50. a 60. letech, probíhaly pod vedením Ivana Borkovského velké terénní odkryvy, které byly s určitým časovým odstupem publikovány. Největší pozornost se stále soustředila na raný stř̌edověk a období přemyslovské vlády. Tomu odpovídají i stěžejní Borkovského studie o kostele Panny Marie (1953) a bazilice sv. Jiří (1962; 1975), ale i přehledové práce o nejstarších kostelech (1961) či jeho rekapitulující publikace, která jako první podala výklad historie Pražského hradu založený především na archeologickém bádání - Pražský hrad v době přemyslovských knižat (1969). Zúročil v ní své výzkumy od 20. let, v celkovém vnímání Pražského hradu ovšem nepřekročil - ani nemohl paradigmata daná mantinely tradičního vnímání památky od 19. století a soudobým požadavkem na výzkum slovanských hradišt' (Maříková-Kubková 2019a).

Druhá etapa v 70. letech přinesla pod vedením Zdeňka Smetánky útlum terénní činnosti, zpracování starých fondů a těžiště výzkumu mimo Pražský hrad. Oproti předešlým desetiletím se ztratila ambice velkorysé přestavby a probíhající stavební práce sledovalo více SÚRPMO. Za třetí fázi, v kontextu celé historie pracoviště velmi významnou, považuji nástup nové generace na počátku 80. let, kdy se znovu začala uplatňovat archeologická památková péče a vrátily se velké terénní výzkumy. Zvyšuje se i badatelská aktivita, objevují se nová témata. Archeologové se věnují jak materiální kultuře, tak stavebnímu vývoji Hradu, na pořad dne ale přicházejí i metody terénního výzkumu. Kvas, který je na pracovišti patrný, vyústil v roce 1988 v publikování prvního svazku řady Castrum Pragense, která byla koncipována jako prostor pro archeologické, 
stavebněhistorické a umělecko-historické bádání o Pražském hradě. ${ }^{11} \mathrm{~V} 80$. letech se také v souvislosti s Pražským hradem zformovalo téma postmedievální archeologie (Blažková 2019, 192-193) v manifestu publikovaném v Československém časopisu historickém (Smetánka-Žegklitz 1989) a s novou publikační řadou Studies in Post-Medieval Archaeology, jejíž první číslo vyšlo v roce 1990.

\section{Ve službách České republiky}

Po roce 1990 přichází na Hrad nový elán. Cílem je zbavit se nánosů minulého režimu a přivést sem významné architekty českého původu, kteří byli úspěšní $\mathrm{v}$ zahraničí (Bořek Šípek, Eva Jiřičná), a významné architekty domácí (Josef Pleskot, Petr Malinský a další). Tématem je rekonstrukce a nové otevření zchátralých prostor, otevření Hradu studentům (sídlo CEU) a vytvoření prostoru pro kulturu. Mění se i vztah mezi ARÚ, KPR a Správou Pražského hradu (dále SPH), která byla zrrízena v roce 1993. „Ke správě majetku a výkonu služeb ve prospěch Kanceláře prezidenta republiky, $k$ podniceni kulturni, společenské a podnikatelské činnosti v areálu Pražského

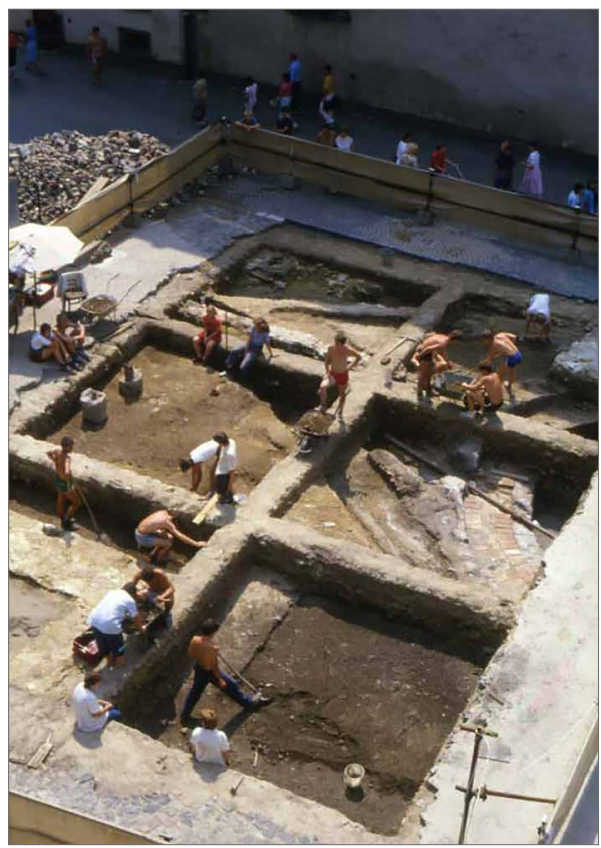

Obr. 7. Pražský hrad, Jiřské náměstí, výzkum v 80 . letech 20. století. Zdroj archiv ARÚ.

Abb. 7. Prager Burg, St. Georgsplatz, Grabung in den 1980er Jahren. Quelle Archiv des Archäologischen Instituts der Akademie der Wissenschaften in Prag.

\section{hradu, $k$ uspokojeni mnohostranných zájmů}

občanů České republiky a návštěvníků Pražského hradu, k zajištění údržby, rekonstrukci a celkového rozvoje Pražského hradu [...]“ (hrad.cz). Odbor památkové péče zůstal pod KPR, ale realizace staveb od najímání projektantů až po stavbu samou přešla do gesce SPH. V 90. letech se zásluhou prezidenta republiky podařilo ještě navázat na starší tradice. Václav Havel povolal na Hrad architekta Bořka Šípka a byla zřízena Komise pro Pražský hrad, ve které vedle osobností z univerzitního, akademického a podnikatelského prostřední zasedal i tehdejší ředitel ARÚ Petr Sommer. Nastalé změny zasáhly majetkovou strukturu. ${ }^{12}$ Hrad se skutečně stal kulturním centrem a součástí práce archeologů byly opět konzultace při stavebních úpravách ${ }^{13}$ a působení v prrípravných výborech velkých výstavních projektů, které v roce 2003 vyvrcholily vybudováním stálé expozice Přiběh Pražského hradu. Na základě smlouvy obnovené v roce 1999 ARÚ pokračoval v záchranných výzkumech. Nově byl, díky dokončenému projektu revitalizace prostor pod III. nádvořím (viz dále), vytvořen i speciální rozpočet na jeho pravidelnou údržbu a monitoring stavu. S novými prezidenty se situace průběžně měnila, do práce zasáhla i nová legislativa. Potřeba diskutovat o podobě a náplni hradních prostor se vytratila, z Jiřského náměstí se stalo tržiště. Trh zasáhl v roce 2017 i archeologickou památkovou péči, vedení SPH vybralo pro revizní výzkum před rekonstrukcí Severního palácového dvorku externí soukromou archeologickou firmu. Zkušenost ovšem ukázala, že pro Pražský hrad toto řešení není vhodné, cenu stoleté praxe a znalost prostředí nelze vyvážit nízkou nabídkou. Problém vyústil v roce 2018 v uzavření nové, čtyřstranné smlouvy mezi KPR, SPH, Akademií věd České republiky a ARÚ.

11 Ediční řada Castrum Pragense se v důsledku nadcházejících změn dočkala pokračování až v roce 1999, ale od té doby vychází pravidelně. 12 Restitucemi se na Hrad vrací církev a rod Lobkoviců.

13 Pro archeology bylo největším počinem té doby pohledové zpřístupnění kostela Panny Marie při rekonstrukci Obrazárny Pražského hradu architektem Bořkem Šípkem v roce 1998. 
Po roce 1990 hradní pracoviště pokračovalo v činnosti. Jeho hlavním odborným partnerem byl i nadále Odbor památkové péče KPR, zatímco administrativně zůstávalo součástí Oddělení archeologie středověku, které vedl Jan Klápště, až do roku 2003. Poté do roku 2007 fungovalo samostatně pod vedením Jana Frolíka. V momentě, kdy se stal vedoucím Oddělení záchranných výzkumů, hradní pracoviště přešlo do tohoto nově zřízeného útvaru. Zástupkyní pro výzkum Pražského hradu se stala Jana Maříková-Kubková. Se změnou na postu ředitele pražského ARÚ v roce 2018 nastaly změny i ve struktuře oddělení a hradní pracoviště se vrátilo pod Oddělení archeologie středověku, jehož vedoucí se stala Jana Maříková-Kubková s Gabrielou Blažkovou jako její zástupkyní.

V 90. letech pokračují na základě požadavků Odboru památkové péče KPR velké terénní odkryvy, které provázejí rekonstrukční práce. Na etapy se pokračuje v průzkumu Jiřského náměstí, Vikářské ulice, po roce 2000 v Jiřské ulici a na dalších místech. Ke slovu se ale vrací i péče o archeologické areály. Pod vedením Ivany Boháčové a Petra Chotěbora byl v rámci grantu Ministerstva kultury v letech 1992-1996 nově zdokumentován a zrestaurován prostor pod III. nádvořím, který v té době doznal už značných škod (Boháčová 1998). Byl také nastaven systém péče, jenž s určitými obměnami pokračuje dodnes.

Se vznikem České republiky se vracejí základní témata českých dějin a počátků české státnosti. Nechybějí v nich samozřejmě archeologické argumenty z Pražského hradu. V mediálním prostoru veřejném i odborném se s historikem Dušanem Třeštíkem střetávají i hradní archeologové I. Boháčová a J. Frolík. A Hrad zůstává především hradištěm a přemyslovským sídlem. První granty udělené nově vzniklými grantovými agenturami se opět soustředí na zpracování celkové podoby Pražského hradu v jednotlivých historických etapách. Za vyvrcholení a zároveň epilog tohoto způsobu vnímání můžeme považovat popularizační knihu Archeologie na Pražském hradě (Frolík-Smetánka 1997), která ještě jednou, téměř třicet let po I. Borkovském, předložila ucelený pohled tentokrát na všechny historické stavební etapy až do raného novověku. $\mathrm{V}$ té době se na hradním pracovišti už rodí jiné př́stupy. $\mathrm{V}$ druhé polovině 90 . let, s př́chodem nové generace, je obnoveno Castrum Pragense a vznikají projekty, které si kladou za cíl nově zpracovat dílčí témata a podat jejich výklad doprovázený edicí relevantních pramenů. Jako první se zpracování dočkaly nejstarší církevní stavby (Frolík et al. 2000). Práci je možné považovat za první v řadě studií, které se snaží, i když ještě ne důsledně, vycházet $\mathrm{z}$ rekonstrukce nálezové situace a terénního pramene. Za důstojné pokračovatele lze pokládat práce o bazilice sv. Jiří (Mašterová 2015) či katedrále sv. Víta (naposledy Maříková-Kubková a kol. 2019). Dalším tématem jsou hroby, pohřebiště a hřbitovy v areálu Pražského hradu a jeho okolí, které zahájil grant Kateřiny Tomkové (Tomková 2006). Na něj pak navázaly projekty I. Boháčové a J. Frolíka (Boháčová-Blažková 2011; Frolík-Smetánka 2014; Frolík 2015; Frolík a kol. 2016). Problematice opevnění se věnovala I. Boháčová (Boháčová 2001).

Strukturování do jednotlivých témat pomohlo začít třídit nahromaděný materiál a informace, stále však chyběl jednotný nástroj k více objektivnímu př́stupu k celé lokalitě. Ten se začal rodit $\mathrm{v}$ průběhu prvního desetiletí nového tisíciletí, částečně pod vlivem domácí archeologické teorie (Neústupný 1994). Více ale zapůsobila účast v mezinárodních projektech (AREA; Schlanger-Maříková-Kubková 2008), které zprostřredkovaly myšlenky teorie míst paměti (Nora 1984), fenomenologie architektury (Norberg-Schulz 1980) a později i teorie kulturních vrstev (Assmann 2012). Potkaly se s novými technickými možnostmi a zrodila se tak myšlenka Archeologického atlasu Pražského hradu. V rámci něj byl zrekonstruován georeliéf (naposledy Herichová 2020), který slouží jako základ všech dalších úvah o sídelním vývoji. Na to pak navazují důsledné revize, pokud je to možné i v terénu, rekonstruování nálezových situací a jejich modelování. Ty jsou pak konfrontovány s georeliéfem. Výsledky jsou promítány do celkové rekonstrukce jednotlivých stavebních fází a přinášejí i nové možnosti vnímání vývoje funkce Pražského hradu a pochopení struktury jeho jednotlivých areálů. ${ }^{14}$ Již tradiční spolupráce s odborníky z oblasti prŕírodních věd

14 Pro širší veřejnost vyvijíme webové stránky www.prazsky-hrad.cz, na nichž si lze - zatím v omezené míre - výsledky mapování a modelování prohlédnout. 
byla rozšířena o specialisty na stavební technologie. Navázali jsme i úzkou spolupráci s historiky liturgie, historiky archiváři a jazykovědci latináŕi. Výsledky jsou představovány postupně a i s určitými potížemi, protože přináší dost odlišný pohled na věci, které se již velmi dlouho považují za jisté (Maříková-Kubková-Herichová 2009; Maříková-Kubková 2018; Maříková-Kubková a kol. v tisku). Postupně se nám pod rukama rodí jiný Pražský hrad, architektonicky rozmanitý a rozdělený, na němž po téměř celý stř̌edověk působily především církevní instituce s mezinárodním obsazením, což se odráží v majetkových poměrech ještě na počátku raného novověku (Maříková-Kubková-Suchý-Blažková v tisku).

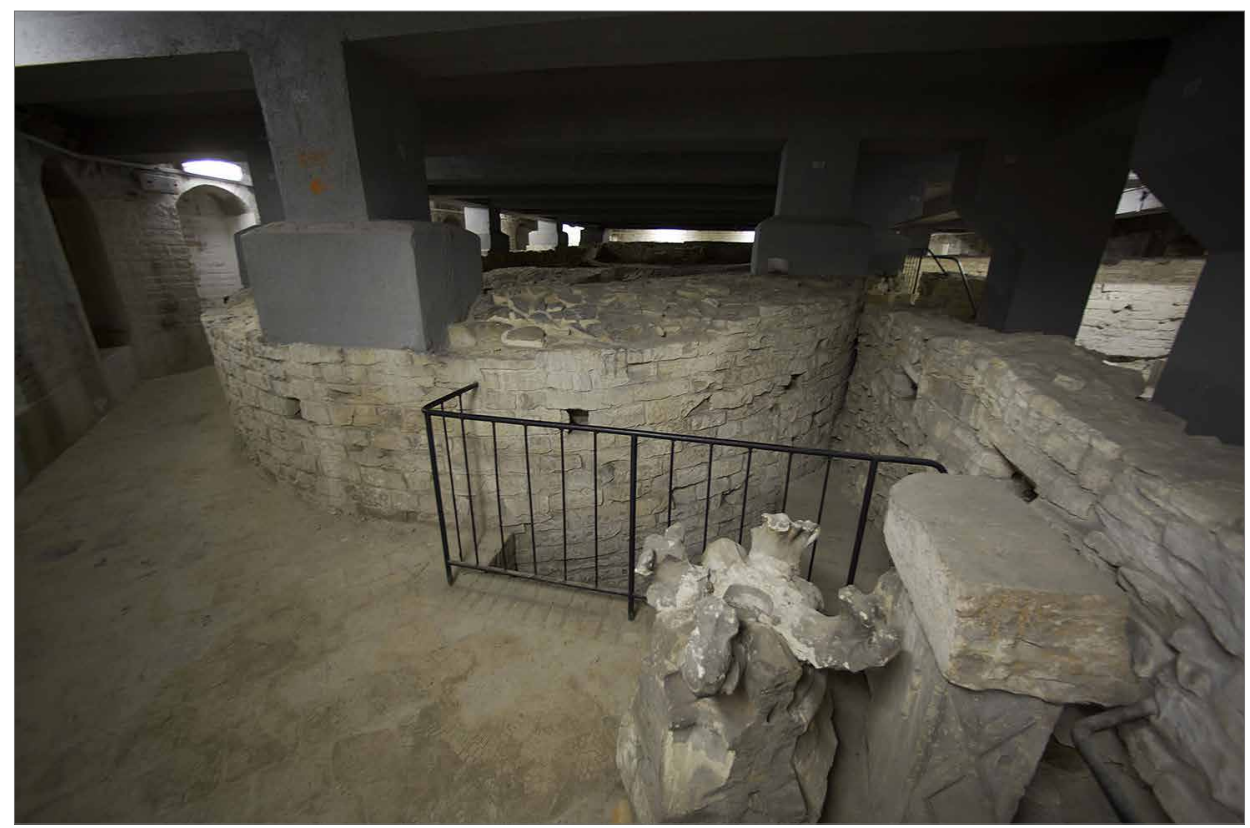

Obr. 8. Pražský hrad, areál pod III. nádvořím, pohled na apsidu kostela zv. sv. Bartoloměje, současný stav. Foto Martin Frouz. Abb. 8. Prager Burg, Areal unter dem III. Burghof, Blick auf die Apsis der sog. Bartholomäuskirche, heutiger Zustand. Foto Martin Frouz.

\section{Závěr}

Archeologické pracoviště na Pražském hradě brzy vstoupí do druhého století své existence. Je velmi nepravděpodobné, že se změní záchranný charakter jeho práce. S výjimkou drobných revizí zde nebude nikdy prostor pro větší badatelský terénní výzkum. Neustálý tlak a nepohodlí ale zdejším archeologům spíše prospívá. Již z 19. století máme velmi dobrou a rozsáhlou dokumentaci výzkumů katedrály sv. Víta, která bez problému obstojí i dnes. V meziválečném období sledujeme postupný vývoj archeologických metod, rozvoj schopností stratigraficky posuzovat nalezené fragmenty. Vznikají i rozsáhlé nálezové fondy nejen (raně) středověkých, ale i novověkých předmětů, z nichž nejdůležitější jsou prakticky okamžitě restaurovány (Blažková-Svobodová 2020, 889-905). Jedna z nejobsáhlejších agend korespondence mezi StAÚ/ARÚ a KPR se týká právě uložení fondů, péče o ně a vznik muzea, v němž by našly uplatnění. Vedle nálezových celků, jaké jsou v archeologii obvyklé, se na Pražském hradě dochoval i soubor vyzvednutých „vzorkư“ terénů. Nejde jen o známé hroby, jako je například hrob bojovníka, dnes umístěný ve 
stálé expozici Příběh Pražského hradu, ale i o „,vzorky“ dlažeb, románských zdiv, pochozích ploch či celých srubových staveb. Většina z nich je dnes uchována v prostoru vykopávek pod III. nádvořím. Naprostým unikátem je pak přenesení základů románského domu v roce 1944 (viz výše).

Novátorem byl nejen Ivan Borkovský, který ještě na sklonku své kariéry v roce 1967, jako jeden z prvních v Československu aplikoval na Jiřském náměstí geofyzikální měření. Nově se zde přistupuje rovněž ke zpracování keramických souborů. V tomto oboru jsou průkopnické především práce Zdeňka Smetánky, již od jeho doktorské práce o středověkých kachlích z Pražského hradu (1958) a v dalším hodnocení keramiky jako archeologického pramene (Doležalová 2015, 42-44). Jeho následovník Jan Frolík začal hned po roce 1990 a krátce po jejím publikování uplatňovat v terénní práci Harrisovu metodu (Harris 1989). Hledání nepřestalo ani s nástupem nových technologií, snažíme se je ale aplikovat v duchu pravidel Archeologického atlasu Pražského hradu, tedy v návaznosti na důsledné revize jak zjištění v terénu, tak dokumentace. Za všechny jmenujme průzkum Královské hrobky (Maříková-Kubková a kol. 2005), který inspiroval mnoho dalších.

Blíží se další generační výměna, blíží se i změna ve vedení KPR a SPH. Zodpovědnost k odkazu, který je na pracovišti Pražský hrad uchováván, nás inspiruje k udržení nejvyššího možného standardu archeologické péče $\mathrm{v}$ úzké spolupráci s Odborem památkové péče KPR, zpracování výzkumů a předání jejich výsledků veřejnosti za všech okolností.

Text vznikl v rámci projektu Technologické agentury České republiky „Skryto pod povrchem“a je věnován Petru Chotěborovi k jeho životnímu výročí.

\section{Prameny}

116 516/50: Žádost o souhlas pana prezidenta republiky k tlumočení blahopřání dr. Borkovskému $\mathrm{k}$ jeho objevu na Pražském hradě, APH, 400 000, inv. č. 209.

304 050/53: Dohoda o způsobu práce archeologického výzkumu Pražského hradu a jeho poměru ke KPR, APH, 400 000, inv. č. 209.

400 408/70: Dopis Archeologického ústavu Kanceláři prezidenta republiky s kresbou situace v terénu, AKPR, fond 6030 .

400 289/57: Návrh směrnic o pracovním postupu při svolávání a jednání vědecké rady KPR s návrhem na složení vědecké rady, APH, 400 000, inv. č. 176.

400 368/63: Archeologický průzkum PH, informace o schůzce s ředitelem Arch. ústavu ČSAV 16. 1, 63, APH, 400 000, inv. č. 139.

401 273/80: Pražský hrad - III. nádvoří - posudek stavu únosnosti železobetonové konstrukce, AKPR, fond 6030.

401 753/60: Pražský hrad, archeologické vykopávky pod III. nádvořím. Prohlídka, APH, 400 000, inv. č. 209.

401 167/48: Seznam výloh na částečné dokončení úpravy Palácového dvora, APH, Palácový dvůr, 404 807/64 (1948-1966), inv. č. 180.

402 380/62: Pražský hrad, archeologické vykopávky pod III. nádvořím. Materiál pro konzervační účely, APH, 400 000, inv. č. 139.

402 756/50: KPR, Archeologický výzkum na Pražském hradě, provádění financování, APH, 400 000, inv. č. 209.

402 846/71: Archeologický výzkum při rekonstrukci Lobkovického paláce, dopis ARÚ (podepsán Z. Smetánka), AKPR, fond 6161.

402 138/60: Vykopávky pod III. nádvořím, APH KPR, 400 000, inv. č. 180.

402 352/72: Dopis ze dne 15. 5. 1972 ARÚ (podepsán Zdeněk Smetánka) KPR, s fotografiemi, AKPR, fond 6030.

402 756/50: Archeologický výzkum na Pražském hradě - provádění a financování, dopis StAÚ KPR, podepsán Jaroslav Böhm, APH KPR, 400 000, inv. č. 209.

402 902/50: Dopis StAÚ KPR, podepsán Jaroslav Böhm, APH KPR, 400 000, inv. č. 209. 
402 380/62: Pražský hrad, archeologické vykopávky pod III. nádvořím. Materiál pro konservační účely, APH KPR, 400 000, inv. č. 180.

403 744/59: Stavební a památková péče o Pražský hrad. Zřízení samostatného projekčního střediska, APH KPR, 400 000, inv. č. 209.

403 065/76: Smlouva na sledování trhlin a kontrolní nivelace, KPR - SÚRPMO, AKPR, 400 000, fond 6040. 404 686/58: Klášter sv. Jiří na Pražském hradě, rekonstrukce, archeologické nálezy, APH KPR, 400000 , inv. č. 209.

405 136/71: Archeologický výzkum „Dolní Jelení př́íkop“, dopis ARÚ (podepsán Z. Smetánka) AKPR, fond 6030.

406 023/76: Katedrála sv. Víta, průzkum fyzikálních poměrů v Královské hrobce, AKPR, fond 6121.

Deník 1918-1919: Stavební deník 1918-1919 (18. 11. 1918-31. 12. 1919), APH KPR, Osobní fond hradního stavitele Karla Fialy (1891-1939), 301.

Deník 1925: Deník vykopávek - 1925 (4. VI. - 27. VII.), fond Stavební správy, inv. č. Ss IX/1-3.

Deník 1926: Deník vykopávek - 1926 (20. IV. - 7. VI.), fond Stavební správy, inv. č. Ss IX/1-6.

H2240/46: Klášter sv. Jiří, pronájem místností hradní stráži, APH, 400 000, inv. č. 209.

Zs 580/44.-J.: Dopis KPR o návštěvě K. M. Swobody, APH, 400 000, inv. č. 180.

\section{Literatura}

ASSMANN, A., 2012: Cultural Memory and Western Civilization: Functions, Media, Archives. Cambridge. BARTLOVÁ, M., v tisku: Dějiny českých dějin umění 1945-1969. Věda o umění slouží vědě o člověku.

BLAŽKOVÁ, G., 2019: Minulost skončila včera. In: Kuna, M. a kol., Sto let v archeologii. Objevy, nálezy a expedice Archeologického ústavu v Praze 1919-2019, 192-193. Praha.

BLAŽKOVÁ, G.-SVOBODOVÁ, L., 2020: Poznávání vývoje restaurátorských technik keramiky na základě studia nálezových deníků z výzkumů na Pražském hradě - Entwicklung restauratorischer Techniken für Keramik im Lauf der Zeit, AH 45, 889-905.

BOHÁČOVÁ, I., 2001: Pražský hrad a jeho nejstarší opevňovací systémy. In: Pražský hrad a Malá Strana, 179-301. Praha.

BOHÁČOVÁ, I., ed., 1998: Archeologický areál III. nádvoří Pražského hradu. Průvodce problematikou archeologickými prameny. Zpráva projektu „Záchrana a dlouhodobá ochrana archeologického areálu pod deskou III. nádvoří Pražského hradu“ (MK ČR, KZ97P02OPP006).

BOHÁČOVÁ, I.-BLAŽKOVÁ, G., 2011: Pohřebiště na Loretánském náměstí v Praze - Hradčanech. Archeologický výzkum Ivana Borkovského a jeho výsledky. Castrum Pragense 11. Praha.

BORKOVSKÝ, I., 1951: Nález kostela Panny Marie na Pražském hradě (předběžná zpráva). In: Význam objevu nejstaršího kostelíka na Pražském hradě, 71-93. Praha.

- 1953: Kostel Panny Marie na Pražském hradě, PA XLIV, 129-200.

- 1961: K otázce nejstarších kostelů na Pražském hradě, PA LI, 332-387.

- 1962: Bazilika a klášter sv. Jiří na Pražském hradě. Praha.

- 1968: recenze Anežka Merhautová: Bazilika sv. Jiří na Pražském hradě, PA LIX, 283-293.

- 1969: Pražský hrad v době přemyslovských knížat. Praha.

- 1975: Svatojiřská bazilika a klášter na Pražském hradě. Praha.

- 2008: Pražský hrad. In: Castrum Pragense 6, 5-21. Praha.

CIBULKA, J., 1934: Václavova rotunda svatého Víta. In: Svatováclavský sborník I, 230. Praha.

DOLEŽALOVÁ, K., 2015: Výzkum vrcholně a pozdně středověké keramiky na území České republiky se zaměřením na deskripční systémy a třídění keramiky podle technologie výroby, Acta FF ZČU 7, č. 2, 39-66.

FIALA, K., 1933: Pražský hrad v době románské. Praha.

FROLÍK, J., 2008: Achtzig Jahre Archäologie der Prager Burg. In: Castrum Pragense 8, 31-46. Praha.

- 2015: Pohřebiště u kostela Panny Marie a na II. nádvoří Pražského hradu. Díl I. Castrum Pragense 14. Praha.

FROLÍK, J. a kol., 2000: Nejstarší sakrální architektura Pražského hradu. Castrum Pragense 3. Praha. 
- 2016: Pohřebiště ve vnitřním areálu Pražského hradu Castrum Pragense 15. Řada ABG (Archeologie Bioarcheologie - Genetika). Praha.

FROLÍK, J.-SMETÁNKA, Z., 1997: Archeologie na Pražském hradě. Praha.

- 2014: Pohřebiště v Lumbeho zahradě na Pražském hradě. Castrum Pragense 12. Praha.

HALATA, M.-KARASOVÁ, D.-ŠULA, M., 2013: Na slunečné straně. Městský trakt Pražského Hradu jako Habsburské sídlo 1800-1918. Praha.

HARRIS, E. C., 1989: Principles of archaeological stratigraphy. 2nd edition. London - San Diego - New York - Boston - Sydney - Tokyo - Toronto.

HERICHOVÁ, I., 2020: Vrch hradní. Vývoj georeliéfu Pražského hradu v raném středověku. Castrum Pragense 16. Praha.

HEROLD, E., 1884: Malerische Wanderungen durch Prag. [II. Die Burg]. Praha.

HILBERT, K., 1915: Svatováclavská kaple v chrámě sv. Víta v Praze. In: Umělecké poklady Čech. Sbírka význačných děl výtvarného umění v Čechách od nejstarších dob do konce XIX. století. Sv. 2. Štencův grafický kabinet (Wirth, Z., ed.), 14-19. Praha.

- 1917: Proslov stavitele dómu architekta Kamila Hilberta o valné schůzi. In: Výroční zpráva Jednoty pro dostavbu chrámu sv. Víta za správní rok 1916, 58-59. Praha.

KUNA, M. a kol., 2019: Sto let v archeologii. Objevy, nálezy a expedice Archeologického ústavu v Praze 1919-2019, Archeologický ústav AV ČR. Praha.

MAŘÍKOVÁ-KUBKOVÁ, J., 2008: Die Rolle der Archäologie beu der Formierung der Symbolik der Prager Burg. In: Castrum Pragense 8, 95-104. Praha.

- 2018: Úloha kultu a církevních center ve formování Pražského hradu v raném středověku - The role of cult and church centers in the formation of Prague Castle in the early Middle Ages. In: Kostel Panny Marie na Pražském hradě: Dialog nad počátky křest’anství v Čechách. Prameny české historie (Štefan, I.-Wihoda, M., edd.), 100-130. Praha.

- 2019: Hmatatelné důkazy pro českou historii. In: Kuna, M. a kol., Sto let v archeologii. Objevy, nálezy a expedice Archeologického ústavu v Praze 1919-2019, 44-45. Praha.

- 2019a: Východní kurz. In: Kuna, M. a kol., Sto let v archeologii. Objevy, nálezy a expedice Archeologického ústavu v Praze 1919-2019, 88-89. Praha.

- 2019b: Kostel nalezený a ztracený. In: Kuna, M. a kol., Sto let v archeologii. Objevy, nálezy a expedice Archeologického ústavu v Praze 1919-2019, 202-203. Praha.

MAŘÍKOVÁ-KUBKOVÁ, J. a kol., 2005: Předběžná zpráva o průzkumu staré královské hrobky v chóru katedrály sv. Víta na Pražském hradě, Castrum Pragense 6, 99-124. Praha.

MAŘÍKOVÁ-KUBKOVÁ, J. a kol., 2019: Katedrála viditelná a neviditelná. Průvodce tisíciletou historií katedrály sv. Víta. I, II. Praha.

MǍ̌ÍKOVÁ-KUBKOVÁ, J., a kol., v tisku: Otázka stavebního vývoje, patrocinia a funkce románské kaple na III. nádvoř́í.

MAŘÍKOVÁ-KUBKOVÁ, J.-HERICHOVÁ, I., 2009: Archeologický atlas Pražského hradu - The archaeological atlas of Prague castle. Castrum Pragense 10. Praha.

MǍ̌ÍKOVÁ-KUBKOVÁ, J.-SUCHÝ, M.-BLAŽKOVÁ, G., v tisku: Space and Community. Church as a Factor in Transforming of Urban Area (the Hradcany-Prague Castle Case).

MAŠTEROVÁ, K., 2015: Bazilika a kláštor sv. Jiří na Pražskom hradě vo svetle archeologického výskumu. Disertační práce, Ústav pro archeologii FF UK, Praha.

MĚCHURA, P., 2016: Úpravy a prezentace Pražského hradu v období první republiky. Disertační práce, Ústav etnologie FF UK, Praha.

NEČÁSEK, F., 1951: Projev na konferenci archeologů a historiků na Pražském hradě. In: Význam objevu nejstaršího kostelíka na Pražském hradě, 15-19. Praha.

NEUSTUPNÝ, E., 1994: Settlement area theory in Bohemian archaeology, PA - Supplementum 1, $248-258$.

NORA, P., 1984: Les Lieux de mémoire. Paris.

NORBERG-SCHULZ, Ch., 1980: Genius Loci. Towards a Phenomenology of Architecture. New York.

PACHTA, J., 1951: Projev na konferenci archeologů a historiků na Pražském hradě. In: Význam objevu nejstaršího kostelíka na Pražském hradě, 46-52. Praha. 
PETRASOVÁ, T., 2019: Jednota pro dostavění chrámu sv. Víta na Pražském hradě. In: Maříková-Kubková, J. a kol., Katedrála viditelná a neviditelná. Průvodce tisíciletou historií katedrály sv. Víta, 522-525. Praha. ROLLOVÁ, V., 2019: Pražský hrad na cestě ke komunistické utopii (1948-1968). Praha.

SCHLANGER, N.-MǍ̌íKOVÁ-KUBKOVÁ, J., 2008: On lieux de mémoire and other archaeological constructs. Some preliminary considerations. In: Castrum Pragense 8, 23-30. Praha.

SMETÁNKA, Z., 1958: Kachle na Pražském hradě (Část 1. Příspěvek k datování tyglíkového kachle) - Tiles at Prague Castle (Part 1. Contribution to dating Tiegelkacheln), PA XLIX, 248-264.

SMETÁNKA, Z.-ŽEGKLITZ, J., 1989: Historie a postmedievální archeologie, ČČH 37, 728-738.

STARCOVÁ, M., 2019: Mezi vědou a politikou. In: Kuna, M. a kol., Sto let v archeologii. Objevy, nálezy a expedice Archeologického ústavu v Praze 1919-201, 101-105. Praha.

ŠINDELKOVÁ, M., 2019: Sochařská a malířská výzdoba katedrály sv. Víta od konce první světové války po současnost. In: Maříková-Kubková, J. a kol., Katedrála viditelná a neviditelná. Průvodce tisíciletou historií katedrály sv. Víta, 708-815. Praha.

TOMKOVÁ, K., 2006: Pohřbívání na Pražském hradě a jeho předpolích. Díl I, II. Castrum Pragense 7. Praha. VLČEK, E., 1997: Nejstarší Přemyslovci. Praha.

VOBOŘILOVÁ-KADLECOVÁ, Ž., 2019: Památková péče na území Prahy v období protektorátu Čechy a Morava. Disertační práce, Ústav dějin křest’anského umění, Katolická teologická fakulta UK, Praha.

\section{Internetové zdroje}

hrad.cz: https://www.hrad.cz/cs/prezident-cr/sprava-prazskeho-hradu/statut, cit. 25. 9. 2020.

\section{Zkratky}

$\begin{array}{ll}\text { AKPR } & \text { Archiv Kanceláře prezidenta republiky } \\ \text { APH } & \text { Archiv Pražského hradu } \\ \text { AREA } & \text { Archives of European Archaeology, evropský projekt Programu Culture 2000 } \\ \text { ARÚ } & \text { Archeologický ústav Akademie věd, Praha (ve všech obměnách po roce 1953) } \\ \text { CEU } & \text { Central Europe University } \\ \text { OPP KPR } & \text { Odbor památkové péče Kanceláře prezidenta republiky } \\ \text { SPH } & \text { Správa Pražského hradu } \\ \text { StAÚ } & \text { Státní archeologický ústav (1919-1953) } \\ \text { ÚDU } & \text { Ústav dějin umění Akademie věd (ve všech obměnách po roce 1953) } \\ \text { ÚTAM } & \text { Ústav teoretické a aplikované mechaniky }\end{array}$

\section{Zusammenfassung}

In den Diensten der Tschechoslowakei. Die archäologischen Ausgrabungen auf der Prager Burg im 20. Jahrhundert

Wohl jeder Beitrag über die Prager Burg beginnt mit einer Schilderung ihrer Außergewöhnlichkeit, und zwar nicht nur im Rahmen der Geschichte der Länder Böhmens, sondern im gesamteuropäischen Zusammenhang. Der zentrale Sitz der wichtigsten kirchlichen und weltlichen Institutionen, die sich dort seit dem frühen Mittelalter entfaltet hatten, ist spätestens seit der ersten Hälfte des 19. Jahrhunderts einer der wichtigsten Forschungsbereiche der tschechischen Geschichtsschreibung. Die Vorstellungen von der mittelalterlichen und frühneuzeitlichen Geschichte der Burg waren schon immer und sind bis heute eng mit den Vorstellungen über die ganze tschechische Geschichte verwoben und haben auch auf die Ausbildung der tschechischen nationalen Identität 
einen direkten Einfluss ausgeübt. Diese Tatsache hat nicht nur ein nicht nachlassendes Interesse der Fachwelt und Öffentlichkeit angeregt und Raum für Forschung und Finanzmittel geschaffen, sondern auch die Interpretationen der Forschungsergebnisse belebt, die den Diskursen der jeweiligen Zeit und der gesellschaftlichen Nachfrage unterlagen.

Die Geschichte der Grabung können wir auf verschiedene Arten und Weisen angehen. Der erste und bisher nahezu universal angewandte Ansatz beurteilt die Erfolge und Misserfolge der jeweiligen Abteilung anhand der durchgeführten Grabungen, erschienenen Büchern, Bearbeitung der Befunde und deren Aussagen. Eine andere Möglichkeit bietet die Untersuchung der Beziehung zwischen Archäologischem Institut, der Kanzlei des Präsidenten der Republik und weiteren Institutionen, die an der Erforschung und der Rekonstruktion der Gebäude der Burg beteiligt waren. Ein solcher Vergleich bietet die einzigartige Gelegenheit, ein plastisches Bild von der Bedeutung der Archäologie und von dem Respekt zu erhalten, den sie zu bestimmten Zeiten genoss, von den Forderungen, die an sie gestellt wurden, aber auch von den Grenzen, innerhalb derer sie sich bewegen musste.

Die erste Forschungsetappe verlief in der zweiten Hälfte des 19. Jahrhunderts, als die Architekten Josef Mocker und Kamil Hilbert die Rekonstruktion und Fertigstellung des Veitsdoms leiteten. Nach und nach entdeckten sie Teile einer romanischen Basilika und einer vorromanischen Rotunde. Die wohl wichtigste Entdeckung, die vor dem Ersten Weltkrieg in der Gesellschaft starken Anklang fand, war der Fund der Südapsis der vorromanischen Rotunde mit dem ursprünglichen Grab des hl. Wenzel. Damals hat sich bereits gezeigt, wie groß das Mitspracherecht der Archäologie bei der Konstruktion der Symbolik der Prager Burg haben würde.

In der zweiten zwischenkriegszeitlichen Etappe, als im Zusammenhang mit dem Umbau der Burg zum Sitz des ersten Tschechoslowakischen Präsidenten eine wirklich groß angelegte archäologische Grabung in Gang kam. Der Umfang und die Bedeutung der Arbeiten haben die Archäologen des Staatlichen Archäologischen Instituts beschäftigt, die seit 1925 bis heute dort tätig sind.

Während des Zweiten Weltkrieges wurden die Forschungsarbeiten stark begrenzt, mit Ausnahme der Grabung auf dem Hradschiner Platz wurden nur Instandhaltungsarbeiten im archäologischen Areal vorgenommen und Funde verarbeitet.

Als dritte Etappe können wir die Zeitspanne zwischen 1945/1948 und 1989 ansprechen, die auf drei Phasen unterteilt werden kann. Die 50er und 60er Jahre standen im Zeichen ehrgeiziger Projekte und bedeutender Entdeckungen. Die 60er brachten einen weiteren Rückgang, der durch Veränderungen in der Kanzlei des Präsidenten der Republik und im Archäologischen Institut verursacht wurde. Die dritte Phase beginnt dann Anfang der achtziger Jahre, als mit dem Antritt einer neuen Generation und mit neuen Bauprojekten die großen Grabungen wieder aufgenommen wurden. Gleichzeitig wurde auch die Forschungstätigkeit intensiviert, die in der Notwendigkeit gipfelte, die eigene Publikationsreihe Castrum Pragense herauszugeben, wo auch das erste Manifest der postmediävalen Archäologie veröffentlicht wurde.

Die vierte Etappe nach 1990 stand im Zeichen von nicht enden wollenden Bauarbeiten und den damit verbundenen großen Grabungen. Bei der Verarbeitung der Befunde führte die neue Archäologengeneration wiederum einen Schub herbei. Noch gegen Ende der 90er Jahre kam das Bestreben auf, sich vom Druck der historischen Forschung zu befreien und eine eigene Quellenedition aufzubauen, auf deren Grundlage man dann die Entwicklung der ganzen Burg beurteilen würde. Nach und nach entstanden so Arbeiten, die die älteste Kirchenarchitektur, die Gräberfelder und Friedhöfe, Befestigungsanlagen und ferner dann auch ausgewählte Bereiche der materiellen Kultur zum Thema hatten. Diese Bemühungen mündeten dann auch in das Projekt eines Archäologischen Atlas der Prager Burg, an dem bis heute gearbeitet wird.

Fast ein ganzes Jahrhundert lang waren die Archäologen Teil des Lebens der Prager Burg, ohne deren Eingriff bzw. Aufsicht praktisch keine Eingriffe in den Boden durchgeführt werden können. Die Ergebnisse ihrer Arbeiten spiegeln sich in den durchgeführten Bauprojekten wider. Sie sind an Ausstellungen, Publikationen und anderen Projekten beteiligt. 
Der vorliegende Text entstand im Rahmen des Projekts der Technologischen Agentur der Tschechischen Republik „Verborgen unter der Oberfläche“ und ist Petr Chotěbor zu seinem Lebensjubiläum gewidmet.

Mgr. Jana Maříková-Kubková, Ph.D., Archeologický ústav AVČR, Praha, v. v. i., Letenská 4, 11801 Praha 1 , Česká republika, marikova@arup.cas.cz 
